\title{
Impact of Sustainable Supply Chain Management Practices on Egyptian Companies' Performance
}

\author{
Ola Mamdouh Mahmoud Hamdy ${ }^{1}$, Khaled Kadry Elsayed ${ }^{2}$, Bassam Elahmady ${ }^{2}$
}

\begin{abstract}
The adoption of the Sustainable Supply Chain Management practices by companies in the private sector of Egypt aids to achieve its sustainable development strategy: Egypt Vision 2030, which aligns with the seventeen SDGs launched by the United Nations in 2015. There is a trade-off between sustainable development and economy. The trade-off lies between the benefits that result from adopting environmental, social or resilient practices by companies, versus the costs incurred due to conducting these practices. The research problem is that companies in Egypt regard sustainable practices as a burden to their profitability and continuity. In addition to that, companies do not link application of Sustainable Supply Chain Management (SSCM) practices with their performance. The hypothesis tests whether or not there is a significant impact for applying Sustainable Supply Chain Management (SSCM) practices on the company's performance measures. The research studies the impact of this application on the economic, environmental and operational performance of these companies. A survey tool is designed to collect the data from managers and employees in the supply chain departments of companies that are listed on the Egyptian corporate responsibility index (S\&P/ EGX ESG Index) and the sample is expanded by including their market peer companies in the EGX100.
\end{abstract}

Keywords: Egypt, Sustainable Supply Chain Management, Green Supply Chain Management, Social Sustainability, Resilient Supply Chain, Performance

\section{Introduction}

Sustainability is currently a major concern on the international and local levels. It is a multi-discipline issue due to its broad nature and applicability across different specialisations. In this research, sustainability is examined from a business perspective related to the sustainability of the supply chain and its impact on a company's performance. Sustainable Supply Chain Management research is mainly derived from the link between the two main streams of research, supply chain management and sustainable development. The supply chain concept has gradually developed from the original one, whose focus is on purchasing functions and inventory management, to a more comprehensive concept. On the other side, "sustainability is about ensuring that our choices and actions are not only economical but also environmentally and socially responsible. It is the development that meets the needs of the present without compromising the ability of future generations to meet their needs" (Brundtland Commission, 1987). 


\section{Literature Review and Hypotheses Development}

The Sustainable Supply Chain Management has multiple definitions. A comprehensive literature review by Ahi and Searcy (2013) analysed definitions for Green and Sustainable Supply Chain Management. It clarified that Sustainable Supply Chain Management (SSCM) is an extension of Green Supply Chain Management (GSCM). That extension lies mainly in both the social and the resilient characteristics of business sustainability. In this paper, the researcher considered SSCM practices to comprise GSCM practices in addition to both the social and the resilient aspects of the supply chain (Ahi \& Searcy, 2013). The following is an elaboration of these practices.

\subsection{Green Supply Chain Management}

Green Supply Chain Management has emerged as an important organisational philosophy to achieve corporate profit by reducing environmental risks while improving ecological efficiency of these organisations and their partners (Van Hoek, 1999). According to Zhu, Sarkis and Lai (2008) GSCM has emerged as an effective management tool and philosophy for proactive and leading manufacturing organisations. The scope of GSCM practices' implementation ranges from green purchasing to integrated life cycle management that comprises supply chains flowing from supplier, through to manufacturer, customer, and closing the loop with reverse logistics. This paper considers the five practices that Zhu et al. (2008) utilised: internal environmental management, green purchasing, customer cooperation, eco-design and investment recovery.

\subsection{Social and Resilient Supply Chain Practices}

It is essential to recognise the social impacts across the supply chain stages for companies that are committed to sustainability. Social issues in the supply chain are defined as "product -or process- related aspects of operations that affect human safety, welfare and community development" (Klassen \& Vereecke, 2012). The social supply chain practices that are tested in this paper are collected from previous literature and are categorised according to Klassen and Vereecke's (2012) definition of social issues in the supply chain. This includes five characteristics: healthcare, child labour, philanthropy, workplace safety and fair trade.

Ponomarov and Holcomb (2009) introduce supply chain resilience as "the adaptive capability of the supply chain to prepare for unexpected events, respond to disruptions, and recover from them by maintaining continuity of operations at the desired level of connectedness and control over structure and function." Furthermore, Fiksel (2006) defined resilience in the business context as the capacity for complex industrial systems to survive, adapt, and grow in the face of turbulent change. That definition clarifies explicitly that resilience is an essential variable in the sustainability of a supply chain because the definition contains the term "survive," a synonym to sustain ("survive", 2017). In this research, the resilient practices examined are classified into upstream, downstream and internal operations practices as previously debated by Carvalho, Azevedo and Cruz-Machado (2012). Table 1 includes all SSCM practices and their measures that are investigated in this research. 
Table 1: Sustainable Supply Chain Management practices investigated in this research

\begin{tabular}{|c|c|}
\hline Variables & Measures \\
\hline \multirow{8}{*}{$\begin{array}{l}\text { Internal } \\
\text { Environmental } \\
\text { Management (IEM) }\end{array}$} & Senior managers' commitment to Green Supply Chain Management \\
\hline & Support for Green Supply Chain Management from mid-level managers \\
\hline & Cross functional cooperation for environmental improvement \\
\hline & Total quality environmental management \\
\hline & Environmental compliance and auditing programs \\
\hline & Acquisition of ISO 14001 certification \\
\hline & Existence of environmental management system \\
\hline & Adoption of Life Cycle Assessment technique \\
\hline \multirow{5}{*}{$\begin{array}{l}\text { Green Purchasing } \\
\text { (GP) }\end{array}$} & Suppliers are selected using environmental criteria \\
\hline & Eco-labeling of purchased products \\
\hline & Cooperation with suppliers for environmental objectives \\
\hline & Environmental audit for suppliers' internal management \\
\hline & Suppliers' ISO 14000 certification \\
\hline \multirow{3}{*}{$\begin{array}{l}\text { Customer Cooperation } \\
\text { (CC) }\end{array}$} & Cooperation with customers for environmentally friendly design \\
\hline & Cooperation with customers for cleaner production \\
\hline & Cooperation with customers for green packaging \\
\hline \multirow{3}{*}{ Eco-design (ECO) } & Design of product/ service for reduced consumption of material and/ or energy \\
\hline & Design of product/ service for reuse, recycle and/or recovery of materials \\
\hline & Design of product/ service to avoid or reduce use of hazardous products \\
\hline \multirow{3}{*}{$\begin{array}{l}\text { Investment Recovery } \\
\text { (IR) }\end{array}$} & Investment recovery \\
\hline & Sale of scrap and used materials \\
\hline & Sale of excess capital equipment \\
\hline \multirow{6}{*}{$\begin{array}{l}\text { Social Supply Chain } \\
\text { Practices (SSC) }\end{array}$} & Ensures provision of healthcare to company employees \\
\hline & Ensures that company's suppliers provide healthcare to their employees \\
\hline & Ensures no child labour occurs in any of its supply chain partners \\
\hline & $\begin{array}{l}\text { Participates in programs that serve the community such as reducing hunger, } \\
\text { disease and poverty or help in education }\end{array}$ \\
\hline & Trains employees for workplace safety \\
\hline & Engages in fair trade with your company's upstream suppliers \\
\hline \multirow{10}{*}{$\begin{array}{l}\text { Resilient Supply Chain } \\
\text { (RSC) } \\
\end{array}$} & $\begin{array}{l}\text { Implements Collaborative, Planning, Forecasting and Replenishment (CPFR) with } \\
\text { your suppliers and/or customers }\end{array}$ \\
\hline & Collaborates planning with customers to enable visibility of demand \\
\hline & $\begin{array}{l}\text { Collaborates planning with suppliers to enable alerts of potential supply } \\
\text { disruptions }\end{array}$ \\
\hline & $\begin{array}{l}\text { Exerts efforts that enable reducing lead time (the time elapsed from when the focal } \\
\text { firm places orders on its first tier suppliers to when it delivers to its customers) }\end{array}$ \\
\hline & Your company has procedures in place for monitoring and mitigation of risk \\
\hline & $\begin{array}{l}\text { Your company maps the network that connects the company to its downstream } \\
\text { customers and upstream suppliers by identifying bottle necks (where there's limited } \\
\text { resources) and critical paths (where there's long lead times or single source of } \\
\text { supply) }\end{array}$ \\
\hline & Has one single source of supply for an item or service \\
\hline & $\begin{array}{l}\text { Uses Supply Chain IT software to provide access and reporting of transaction data } \\
\text { between your company and its supply chain members }\end{array}$ \\
\hline & Collaborates with suppliers to track the origin of any defective item \\
\hline & $\begin{array}{l}\text { Collaborates with customers to provide total supply chain traceability for your } \\
\text { products/services }\end{array}$ \\
\hline
\end{tabular}




\subsection{Performance Measurement}

Performance improvement is an important driver for companies to encourage them to apply sustainable management practices. However, the business case for the implementation of Sustainable Supply Chain Management (SSCM) practices has to be proved and laid down for companies in order to adopt these practices. In this paper, the researcher will evaluate three company performance measures: environmental, economic and operational. These are the most cited measures in the related literature adapted from Zhu et al. (2008) and Azevedo, Carvalho and Machado (2011). Table 2 includes performance measurement variables used in this research.

Table 2: Performance measurement variables investigated in this research

\begin{tabular}{|c|c|}
\hline Performance Variable & Measures \\
\hline \multirow{6}{*}{$\begin{array}{l}\text { Environmental Performance } \\
\text { (EnvP) }\end{array}$} & Air emission reduction \\
\hline & Water waste reduction \\
\hline & Solid wastes reduction \\
\hline & Reduction of consumption of hazardous materials \\
\hline & Reduction in frequency of environmental accidents \\
\hline & Improvement of company's environmental situation \\
\hline \multirow{6}{*}{$\begin{array}{l}\text { Economic Performance } \\
(\text { EconP })\end{array}$} & Decrease in cost for materials purchasing \\
\hline & Decrease in cost for energy consumption \\
\hline & Decrease in fee for waste treatment \\
\hline & Decrease in fee for waste disposal \\
\hline & Decrease in fine for environmental accidents \\
\hline & Increase in revenue from green products/ services \\
\hline \multirow{7}{*}{$\begin{array}{l}\text { Operational Performance } \\
\text { (OperP) }\end{array}$} & Increase in amount of products/ services delivered on time \\
\hline & Decrease in inventory level \\
\hline & Decrease in scrap rate \\
\hline & Increase in quality of product/ service \\
\hline & $\begin{array}{l}\text { Increase in product line (a group of related products manufactured } \\
\text { by a single company) }\end{array}$ \\
\hline & Improvement of capacity utilization \\
\hline & Increase in customer satisfaction \\
\hline
\end{tabular}

Based on the previous discussion of green, social and resilient supply chain practices in addition to the company's performance measures, the following hypotheses can be proposed for testing:

H1: There is a significant impact of applying Green Supply Chain Management (GSCM) practices on a company's performance.

H2: There is a significant impact of applying social resilient supply chain (SRSC) practices on a company's performance.

H3: There is a significant impact of applying Green Supply Chain Management (GSCM)) on social resilient supply chain (SRSC).

H4: Social resilient supply chain (SRSC) mediates the relationship between Green Supply Chain Management (GSCM) and a company's performance.

H5: There is a significant impact of applying Sustainable Supply Chain Management (SSCM) practices on a company's performance. 


\section{Methodology}

\subsection{Sample and Data Collection}

The survey instrument is administered using convenience sampling. The researcher limited the study population to the managerial levels and employees in the supply chain and operations management functions in the Egyptian companies listed on S\&P/ EGX \& ESG Index and expanded the sample to their market peer companies listed in EGX100. The companies on the ESG Index are selected because they are distinguished by their application of sustainable practices that have made them eligible to have ranks on that index; in addition to that, they belong to different sectors. Moreover, the market peers were specifically selected based on the industry and the market capital of the companies. The survey consisted of three sections that include (1) company and respondent description, (2) application level of Sustainable Supply Chain Management practices and (3) company's performance measures results.

That yielded a total of 72 companies. The questionnaires were filled out online via a Survey Monkey link sent to the respondents either through e-mail or through LinkedIn. Other questionnaires were filled out manually by respondents upon visits to their companies. The total number of correct filled out questionnaires by the companies' respondents is 204, where 115 responses are from respondents working in companies listed on the ESG Index and 89 responses are from respondents working in companies not listed on the ESG Index.

\subsection{Variables and Measurement}

In this paper, SSCM practices are categorized into two separate independent variables: GSCM (Zhu and Sarkis, 2004) and SRSC (Ahi and Searcy, 2013). Their effect on the company's performance is tested. GSCM is the overall mean of internal environmental management, green purchasing, environmental customer cooperation, eco-design and investment recovery. Moreover, the SRSC is the overall mean of the social and the resilient supply chain practices. And finally the performance dependent variable is the overall mean of environmental, economic and operational variables. GSCM, in addition to SRSC, represent SSCM. The reliability (Cronbach alpha) for the three variables has been calculated: GSCM (0.906), SRSC (0.804) and the company's performance (0.901).

Respondents were asked to indicate to what extent the SSCM practices were implemented in their companies based on a five-point Likert scale ranging from 1 (not considering it) to 5 (applying it successfully). As for the company's performance, respondents were asked to describe the performance results on a scale ranging from 1 (not at all) to 5 (significant). The measures are presented in Tables 1 and 2 .

\subsection{Partial Least Square Structural Equation Model}

Partial least squares (PLS) path modeling is a variance-based structural equation modeling (SEM) technique that is widely used in business and social sciences. PLS is preferred because it achieves increased levels of statistical power with small sample sizes and because it does not make distributional assumptions (Hair, Sarstedt, Hopkins and Kuppelwieser, 2014). PLS path models are defined by two sets of linear equations: the 
measurement model and the structural model. The measurement model specifies the relationships between a latent variable and its observed indicators, whereas the structural model specifies the relationships between the latent variables (Henseler, Hubona \& Ray, 2016). The PLS path model is assessed in three steps (Henseler et al. 2016): first, the evaluation of the overall model, second, the evaluation of the measurement model and third, the evaluation of the structural model.

\subsubsection{Overall Model}

First, a structural equation model was built to investigate the existence of a direct relationship between SSCM practices and a company's performance; however, the goodness-of-fit indices of this model indicated a bad model fit. Another model was built that categorised SSCM practices into two separate latent variables, GSCM (Zhu and Sarkis, 2004) and SRSC (Ahi and Searcy, 2013), and tested their relationships with the company's performance (Figure 1). The model shows the overall explanatory power: the entire specified paths and their coefficients together with the $\mathrm{R}^{2}$ values. It displays three main paths: the relationship between GSCM and Performance and SRSC and performance, in addition to GSCM and SRSC. The hypotheses relationships that are tested are labeled in the figure. The SmartPLS report yielded an SRMR equal to 0.075 which is below 0.08 (the cut-off value for the goodness of fit); this proves that the proposed model is a good fit to the observed data, which allows to proceed to the evaluation of the measurement model.

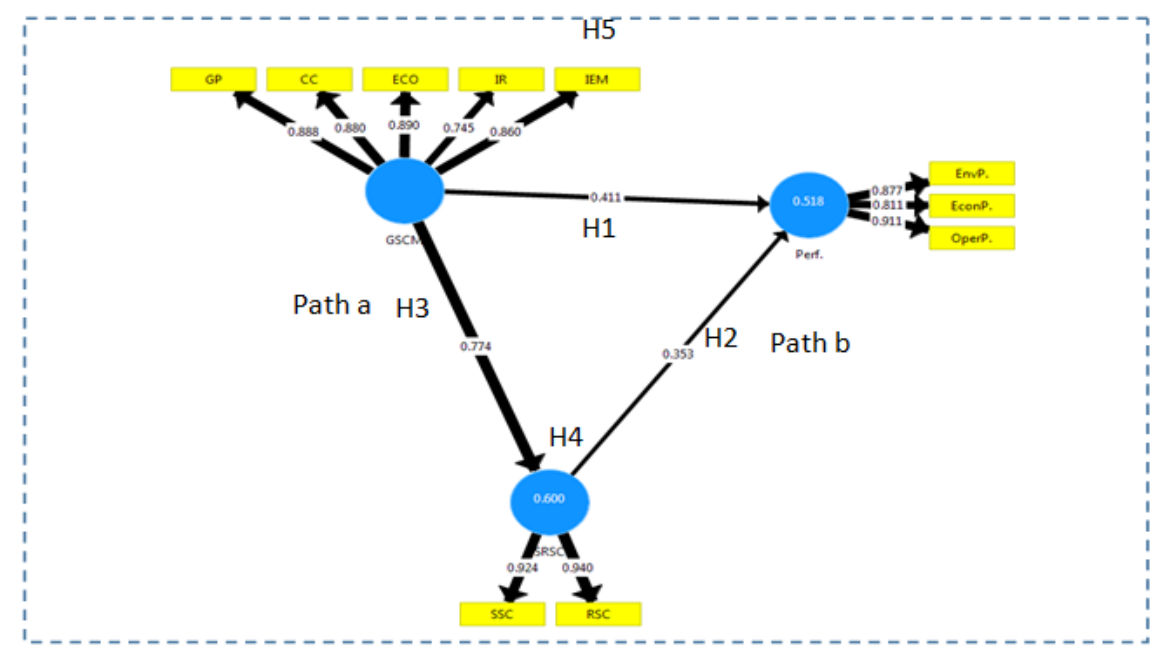

Figure 1: Measurement and structural models demonstrate the relationship between SSCM (GSCM + SRSC) and a company's performance - the proposed framework

Source: SmartPLS output report

\subsubsection{Measurement Model}

The evaluation of the measurement model is conducted through examining a confirmatory factor analysis, internal consistency reliability, convergent validity and discriminant validity. 
A CFA is conducted using SmartPLS 3. The factor loadings of the observed variables to their respective latent variable, GSCM, range between the lowest 0.745 (IR) to the highest 0.891 (ECO). Moreover, the standardised loading estimates of the social supply chain (SSC) and the resilient supply chain (RSC) to their latent variable social resilient supply chain (SRSC) are 0.924 and 0.940 , respectively. And as for performance, the operational performance had the highest loading (0.911) and the lowest was the economic performance (0.811). All loadings are higher than 0.7 (Figure 1) which is a favourable cut-off threshold (Hair, Sarstedt, Hopkins, \& Kuppelwieser, 2014).

The reliability of the three latent variables (GSCM, SRSC and performance) that build the model is verified by calculating the Cronbach's $\alpha$. The level of internal consistency for each construct was acceptable, with the value of $\alpha$ ranging from 0.836 to 0.906 which is above the cut-off level of 0.7 . Moreover, the composite reliability was calculated that yielded values not lower than 0.6 (Henseler, Ringle and Sinkovics, 2009). The average variance extracted (AVE) exceeded the minimum criterion of 0.5 that ranged from 0.730 to 0.869 , thus, convergent validity is verified (Table 3 ).

Table 3: Reliability and validity tests

\begin{tabular}{l|ccc}
\multicolumn{1}{c}{ AVE } & Cronbach's alpha & Composite Reliability \\
\hline (GSCM) & 0.730 & 0.906 & 0.931 \\
(SRSC) & 0.869 & 0.849 & 0.930 \\
Company Performance & 0.752 & 0.836 & 0.901
\end{tabular}

Source: SmartPLS 3 output report

Furthermore, discriminant validity specifies the extent to which a given construct is different from the rest of the other constructs (Kijsanayotin, Pannarunothai, and Speedie 2009). It is assured when the variables have higher loadings in their original factors than in the other constructs (Hair et al., 2014). This can be verified by the cross loading analysis which yielded satisfactory results (Table 4).

Table 4: Cross loading analysis

\begin{tabular}{l|ccc}
\multicolumn{1}{c}{ GSCM } & SRSC & Perf. \\
\hline IEM & 0.860 & 0.537 & 0.695 \\
GP & 0.888 & 0.641 & 0.567 \\
CC & 0.880 & 0.639 & 0.564 \\
ECO & 0.890 & 0.671 & 0.608 \\
IR & 0.745 & 0.651 & 0.635 \\
RSC & 0.757 & 0.940 & 0.661 \\
SSC & 0.683 & 0.924 & 0.587 \\
EconP. & 0.469 & 0.495 & 0.811 \\
EnvP. & 0.601 & 0.592 & 0.877 \\
OperP. & 0.685 & 0.644 & 0.911
\end{tabular}

Source: SmartPLS 3 output report

\subsubsection{Structural Model}

The inner model is assessed by examining the coefficient of determination $\left(\mathrm{R}^{2}\right)$ of the endogenous variables in the model. The fraction of the company's performance 
which is explained by GSCM and SRSC $\left(\mathrm{R}^{2}\right)$ is 0.518 . For SRSC, the variance explained value by GSCM is $60 \%$. That is satisfactory for evaluating the endogenous variables of the model. $\mathrm{R}^{2}$ values are displayed in Figure 1. Inner model is also evaluated through checking the size and the sign of the path coefficients, and reviewing the p-value and confidence interval of these direct effects (Table 5).

Table 5: Significance analysis of the structural model relationships

\begin{tabular}{l|cccccc} 
Relation & Sign & Path & Standard Deviation & t-value & p-value & Sig. \\
\hline GSCM $\rightarrow$ Perf. $(\boldsymbol{H} 1)$ & + & 0.411 & 0.086 & 4.754 & 0.000 & $* * *$ \\
SRSC $\rightarrow$ Perf. $(\boldsymbol{H} 2)$ & + & 0.353 & 0.107 & 3.289 & 0.001 & $* * *$ \\
GSCM $\rightarrow$ SRSC $(\boldsymbol{H 3})$ & + & 0.774 & 0.032 & 24.491 & 0.000 & ***
\end{tabular}

Source: SmartPLS 3 output report

\section{Hypotheses Testing}

A bootstrap procedure that comprises 500 re-samples as recommended by Chin, Marcolin and Newsted (2003) was used to calculate the significance of the path coefficients and the t-values. The bootstrapping procedure generates random samples of observations from the original data set by using a sampling through replacement technique. Table 5 shows that the three main relationships tested were found to be significant at $\alpha$ level of 0.01 . GSCM had a significant positive impact on the company's performance with a path coefficient; 0.411, $t=4.754$ and $p=0.000$, thus the first hypothesis is accepted. It is also found that the SRSC practices had a significant positive impact on a company's performance with a path coefficient; $0.353, t=3.289$ and $p=$ 0.001 , thus the second hypothesis is accepted. As for the impact of GSCM on SRSC, the path coefficient was $0.774, t=24.491$ and $p=0.000$, which verifies a strong significant positive impact between these two latent variables. Thereby the third hypothesis is accepted. This proves that GSCM practices have an essential role in accumulating SRSC practices, which then impacts the company's performance. This would then derive us to test the mediation effect of SRSC.

In the simplest form of mediation, the indirect effect is the product $\mathrm{a} \times \mathrm{b}$ of the two paths from the GSCM to the mediator construct (SRSC) (path a) and from the mediator construct (SRSC) to the dependent construct (performance) (path b) (Nitzl, Roldan \& Cepeda, 2016) (Figure 1). In this study, the researcher adopted the procedures of Preacher and Hayes (2008) in evaluating the mediator (cited in Nitzl et al., 2016). It comprises two conditions: (1) bootstrap the indirect effects where the relationship between the independent variable and the dependent variable must be significant and (2) bootstrap the confidence interval where the upper and lower levels of the interval should not include a zero. According to the bootstrap report output, a significant indirect relationship exists between GSCM and performance with $p$-value $=0.001$ and specifically through SRSC practices (table 6). Moreover, a bootstrap with 95\% confidence interval was calculated for the indirect effect of GSCM practices on the company's performance (Table 7). Since zero is not included in the confidence interval, researcher can assume that there is a significant indirect effect (Preacher and Hayes, 2008; Nitzl, Roldan \& Cepeda, 2016). So both conditions of mediation testing are accomplished. Thus the 
fourth hypothesis is accepted.

Table 6: Specific indirect relationship in the proposed structural equation model

\begin{tabular}{c|ccccc} 
& $\begin{array}{c}\text { Original } \\
\text { Sample (O) }\end{array}$ & $\begin{array}{c}\text { Sample } \\
\text { Mean (M) }\end{array}$ & $\begin{array}{c}\text { Standard } \\
\text { Deviation } \\
(\text { STDEV })\end{array}$ & $\begin{array}{c}\text { T Statistics } \\
(/ O / S T D E V /)\end{array}$ & $\begin{array}{c}p- \\
\text { values }\end{array}$ \\
\hline GSCM $>$ > SRSC $>>$ Perf. & 0.274 & 0.281 & 0.086 & 3.198 & 0.001
\end{tabular}

Source: SmartPLS bootstrap report output

Table 7: Bootstrapped confidence interval for the indirect effect

\begin{tabular}{|c|c|c|c|c|c|c|}
\hline \multirow{2}{*}{$\begin{array}{c}\text { Direct Effect } \\
\text { GSCM } \rightarrow \text { SRSC } \\
\text { (path a) }\end{array}$} & \multirow{2}{*}{$\begin{array}{c}\text { Direct Effect } \\
\text { SRSC } \rightarrow \text { Perf. } \\
\text { (path b) }\end{array}$} & \multirow{2}{*}{$\begin{array}{c}\text { Indirect Effect } \\
\text { GSCM } \rightarrow \text { Perf. } \\
(\text { axb) }\end{array}$} & \multirow{2}{*}{$\begin{array}{l}\text { SE Indirect } \\
\text { Effect }\end{array}$} & \multirow{2}{*}{$\begin{array}{c}\text { t-value } \\
\text { Indirect } \\
\text { Effect }\end{array}$} & \multicolumn{2}{|c|}{$\begin{array}{c}\text { Bootstrapped } \\
\text { Confidence Interva }\end{array}$} \\
\hline & & & & & LL $95 \%$ & UL 95\% \\
\hline 0.774 & 0.353 & 0.274 & 0.086 & 3.198 & 0.102 & 0.446 \\
\hline
\end{tabular}

Source: SmartPLS bootstrap report output

As for the fifth hypothesis, SSCM is an extension to GSCM added to it SRSC (Ahi and Searcy, 2013), and both GSCM and SRSC have a significant positive impact on the company's performance $(\beta=0.411, \beta=0.353$, respectively, with $\mathrm{p}<0.001)$. In addition to that, a significant positive impact exists between GSCM and SRSC $(\beta=0.774, \mathrm{p}=$ $0.000)$ and SRSC acts as a partial mediator between GSCM and performance. Therefore, it can be concluded that there is a significant positive relationship between SSCM and the company's performance. Hence, fifth hypothesis is accepted.

\section{Research Findings and Discussion}

This research aimed to investigate that adopting SSCM practices would improve the company's performance. The results clarified that SSCM practices, composed of GSCM and SRSC practices, have a significant positive impact on a company's performance. In addition, SRSC practices play the role of a mediator between GSCM practices and a company's performance.

The findings of this research are in line with previous literature. There is abundant research in support of GSCM practices' positive impact on a company's performance (H1) (Zhu and Sarkis, 2004; Rao \& Holt, 2005; Azevedo et al., 2011; Laosirihongthong, Adebanjo \& Tan, 2013; deSoussa Jabbour, de Oliveira Frascareli \& Chiapetta, 2015; Vanalle Ganga \& Filho, 2017). In line with Carvalho, Azevedo and Machado (2012), our results confirmed the positive relationship between resilient supply chain practices and company's performance. They debated that resilient supply chain management practices, have a positive significant impact on operational performance in terms of delivery flexibility, product quality and customer service in addition to economic performance in terms of reduced costs of procurement, inventory and manufacturing. Moreover, Carter and Jennings (2002) found out that social supply chain practices significantly affect a company's operational performance in terms of better quality and shorter lead time. Social supply chain practices investigated in their study were socially responsible purchasing, environmental purchasing, human rights (child labour and fair trade), philanthropy and safety. That supports $\mathrm{H} 2$.

As for the H3 and H4, Chu, Yang, Lee and Park (2017) concluded that SRSC practices 
play a partial mediation role between GSCM practices and a company's environmental and operational performance. They argued that the adoption of GSCM practices by the company accumulates the SRSC practices (collaboration with suppliers which they consider cognitive social capital), which in turn affects the company's performance (environmental and operational). This is attributed to the fact that the application of green practices, such as green purchasing and eco-design, by the buyer company would continuously lead to communication and collaboration with the suppliers, which counts as a resilient supply chain practice, to keep and develop consistent perspective on their environmental capabilities. This kind of collaboration, in turn, has a positive impact on the environmental performance of the company. In addition to that, it affects the operational performance of the company positively in terms of better quality and better delivery on time.

And finally, with regard to H5, Janssen, Johnson and Schaltegger (2015) reviewed the academic literature on sustainable performance measurement for SSCM that was published over 20 past years. They found that economic and environmental measures dominated the field and lately social performance measures have been investigated. However the researcher finds that there is a research gap in the resilience measures from the sustainable perspective of a supply chain.

\section{Conclusion, Implications and Research Limitations}

It could be concluded that SSCM practices have an effect on a company's performance. Companies have to explore opportunities in their business operations that would ensure their continuity and profitability (economic perspective), meanwhile reduce the environmental risks and ecological scarcities (environmental perspective) while improving the well-being of people and social equity (social perspective). Table 1 can serve as a checklist for managers to guide them of what practices they can apply that have a positive effect on performance. It is recommended that companies report any sustainable practices they conduct and reveal its impact on the company's performance, nevertheless, publishing sustainability reports on an annual basis that cover all aspects of the triple bottom line.

The government can play a vital role in encouraging companies to adopt sustainability practices. First, it can launch a sustainable public procurement plan. Since the Egyptian government spending accounts for a large percentage of the GDP (12\% in 2015 as per the World Bank records), launching such a plan would spread sustainability practices backward in the supply chain of numerous companies both in the public and the private sectors. Moreover, companies that conduct sustainability practices and report them have to be modeled as best practices. Government could motivate them; either through being ranked on the corporate responsibility index or through financial incentives, as tax reductions or easier access to loans. Meanwhile, government could have business contracts with these companies. Furthermore, it could create less red tape in environmental audits that are conducted by the government representatives.

Future research could test the specific impact of each practice of the GSCM, the resilient supply chain practices or the social supply chain practices on the company's performance. Future research could also consider this effect in specific business sectors. 
This relationship can be examined also in small and medium sized enterprises, or in companies not listed on the EGX.

\section{References}

Ahi, P., \& Searcy, C. (2013). A comparative literature analysis of definitions for green and sustainable supply chain management. Journal of Cleaner Production, 52, 329-341.

Azevedo, S. G., Carvalho, H., \& Machado, V. C. (2011). The influence of green practices on supply chain performance: a case study approach. Transportation research part E: logistics and transportation review, $47(6), 850-871$.

Beske-Janssen, P., Johnson, M. P., \& Schaltegger, S. (2015). 20 years of performance measurement in sustainable supply chain management-what has been achieved?. Supply chain management: An international Journal, 20(6), 664-680.

Brundtland Commission. (1987). World commission on environment and development. Our common future.

Carter, C. R., \& Jennings, M. M. (2002). Social responsibility and supply chain relationships. Transportation Research Part E: Logistics and Transportation Review, 38(1), 37-52.

Carvalho, H., Azevedo, S. G., \& Cruz-Machado, V. (2012). Agile and resilient approaches to supply chain management: influence on performance and competitiveness. Logistics research, 4(1-2), 49-62.

Chin, W. W., Marcolin, B. L., \& Newsted, P. R. (2003). A partial least squares latent variable modeling approach for measuring interaction effects: Results from a Monte Carlo simulation study and an electronic-mail emotion/adoption study. Information systems research, 14(2), 189-217.

Chu, S. H., Yang, H., Lee, M., \& Park, S. (2017). The Impact of Institutional Pressures on Green Supply Chain Management and Firm Performance: Top Management Roles and Social Capital. Sustainability, 9(5), 764.

de Sousa Jabbour, A. B. L., de Oliveira Frascareli, F. C., \& Jabbour, C. J. C. (2015). Green supply chain management and firms' performance: Understanding potential relationships and the role of green sourcing and some other green practices. Resources, Conservation and Recycling, 104, 366-374.

F. Hair Jr, J., Sarstedt, M., Hopkins, L., \& G. Kuppelwieser, V. (2014). Partial least squares structural equation modeling (PLS-SEM) An emerging tool in business research. European Business Review, 26(2), 106-121.

Fiksel, J. (2006). Sustainability and resilience: toward a systems approach. Sustainability: Science, Practice, \& Policy, 2(2).

Henseler, J., Hubona, G., \& Ray, P. A. (2016). Using PLS path modeling in new technology research: updated guidelines. Industrial management \& data systems, 116(1), 2-20.

Henseler, J., Ringle, C. M., \& Sinkovics, R. R. (2009). The use of partial least squares path modeling in international marketing. In New challenges to international marketing (pp. 277-319). Emerald Group Publishing Limited.

Kijsanayotin, B., Pannarunothai, S., \& Speedie, S. M. (2009). Factors influencing health information technology adoption in Thailand's community health centers: Applying the UTAUT model. International journal of medical informatics, 78(6), 404-416.

Klassen, R. D., \& Vereecke, A. (2012). Social issues in supply chains: Capabilities link responsibility, risk (opportunity), and performance. International Journal of Production Economics, 140(1), 103-115.

Laosirihongthong, T., Adebanjo, D., \& Choon Tan, K. (2013). Green supply chain management practices and performance. Industrial Management \& Data Systems, 113(8), 1088-1109.

Nitzl, C., Roldan, J. L., \& Cepeda, G. (2016). Mediation analysis in partial least squares path modeling: Helping researchers discuss more sophisticated models. Industrial management \& data systems, 116(9), 1849-1864.

Ponomarov, S. Y., \& Holcomb, M. C. (2009). Understanding the concept of supply chain resilience. The international journal of logistics management, 20(1), 124-143.

Preacher, K. J., \& Hayes, A. F. (2008). Assessing mediation in communication research. The Sage sourcebook of advanced data analysis methods for communication research, 13-54.

Rao, P., \& Holt, D. (2005). Do green supply chains lead to competitiveness and economic performance?. International journal of operations \& production management, 25(9), 898-916. 
Survive. (2017). In Thesaurus. Retrieved from http://www.thesaurus.com/browse/survive (accessed 16 May 2017)

Van Hoek, R. I. (1999). From reversed logistics to green supply chains. Supply Chain Management: An International Journal, 4(3), 129-135.

Vanalle, R. M., Ganga, G. M. D., Godinho Filho, M., \& Lucato, W. C. (2017). Green supply chain management: An investigation of pressures, practices, and performance within the Brazilian automotive supply chain. Journal of cleaner production, 151, 250-259.

Zhu, Q., \& Sarkis, J. (2004, February). Green supply chain management in China. In Photonics Technologies for Robotics, Automation, and Manufacturing (pp. 147-154). International Society for Optics and Photonics.

Zhu, Q., Sarkis, J., \& Lai, K. H. (2008). Confirmation of a measurement model for green supply chain management practices implementation. International journal of production economics, 111(2), 261-273. 